\title{
Carbon-hydrogen and carbon-carbon bond activation with highly electrophilic transition metal complexes
}

\author{
John E. Bercaw \\ Contribution Number 7964 from the Division of Chemistry and Chemical Engineering, \\ California Institute of Technology, Pasadena, California 91125
}

\begin{abstract}
Highly electron deficient scandocene derivatives of the types $\left(\eta^{5}-\mathrm{C}_{5} \mathrm{Me}_{5}\right)_{2} \mathrm{ScR}$, $\left\{\left(\eta^{5}-\mathrm{C}_{5} \mathrm{Me}_{4}\right)_{2} \mathrm{SiMe} \mathrm{e}_{2}\right\} \mathrm{ScR}$ and $\left\{\left(\eta^{5}-\mathrm{C}_{5} \mathrm{H}_{3} \mathrm{CMe}_{3}\right)_{2} \mathrm{SiMe} \mathrm{H}_{2}\right\} \mathrm{ScR}$ catalyze the polymerization of ethylene, the head-to-tail dimerization of $\alpha$ olefins, the cyclization of $\alpha, \omega$ dienes to methylene cycloalkanes, and the branching of 1,4 pentadienes to isoprenes. The mechanisms of the individual steps have been studied. Key steps involve sequential and reversible olefin insertion $/ \beta \mathrm{H}$ elimination $/ \beta$ alkyl elimination, the last of which is particularly facile in these systems. $\left[\left\{\left(\eta^{5}-\mathrm{C}_{5} \mathrm{Me}_{4}\right) \mathrm{Me}_{2} \mathrm{Si}\left(\eta^{1}-\mathrm{NCMe}_{3}\right)\left(\mathrm{PMe}_{3}\right) \mathrm{Sc}(\mu-\mathrm{H})\right]_{2}\right.$, catalyzes the polymerization of $\alpha$ olefins. Evidence is presented in support of a well defined, one component catalyst system with all scandium centers functioning alike.
\end{abstract}

\section{INTRODUCTION}

Organometallic compounds of scandium resemble those of aluminum, particularly in their tendency to form dimeric or oligomeric structures with bridging alkyl or hydride groups. Recently our research group has reported the synthesis and some features of the reactivity of alkyl and hydride derivatives of bis(pentamethylcyclopentadienyl) scandium, $\mathrm{Cp}{ }_{2} \mathrm{ScR}\left(\mathrm{Cp} \mathrm{p}^{\star}=\left(\eta^{5}-\mathrm{C}_{5} \mathrm{Me} \mathrm{e}_{5}\right)\right)$ (ref.1). The bulky $\left(\eta^{5}-\mathrm{C}_{5} \mathrm{Me}_{5}\right)$ ligands prevent dimerization and restrict the types of ligands which can coordinate to the formally 14 electron, $d^{0}$ scandium center. We have suggested the name "sigma bond metathesis" for a dominant reaction type for these highly electrophilic compounds:

$$
\begin{aligned}
& C p^{*}{ }_{2} S c-R+R^{\prime} \cdot H \underset{H}{ } \underset{C^{*}}{\longrightarrow} p^{*} S c-R^{\prime}+R-H \\
& \left(R, R^{\prime}=\right.\text { hydride, alkyl, alkenyl, aryl, alkynyl) }
\end{aligned}
$$

More recently we have turned our attention to the reactivity of these compounds with olefins. Early indications were that they readily polymerize ethylene without coordinating bases or co-catalysts, common complications for Ziegler-Natta polymerizations using group 4 transition metal catalysts. We have therefore undertaken a study of this model system (ref. 2).

$$
\mathrm{Cp}^{*}{ }_{2} \mathrm{Sc}-\mathrm{R}+\mathrm{n} \mathrm{CH}_{2}=\mathrm{CH}_{2} \longrightarrow \mathrm{Cp}^{*}{ }_{2} \mathrm{Sc}\left(\mathrm{CH}_{2} \mathrm{CH}_{2}\right)_{n} \mathrm{R}
$$

Due to unfavorable steric interactions with the $\left(\eta^{5}-\mathrm{C}_{5} \mathrm{Me}_{5}\right)$ ligands, $\alpha$ olefins do not undergo insertion into the scandium-carbon bonds of $\mathrm{Cp}^{*}{ }_{2} \mathrm{ScR}$; rather, they react by sigma bond metathesis (eq. 1). Less crowded scandocene derivatives were prepared, and, indeed, these proved to be very efficient $\alpha$ olefin dimerization catalysts. Moreover, with 1,4-pentadienes, skeletal rearrangement to isoprenes are observed. A related system with linked cyclopentadienyl and amide ligands $\left\{\left(\eta^{5}-\mathrm{C}_{5} \mathrm{Me}_{4}\right) \mathrm{SiMe}_{2}\left(\eta^{1}-\mathrm{NCM} \mathrm{e}_{3}\right)\right\} \mathrm{ScR}$ catalyzes the polymerization of $\alpha$ olefins in a quasi-living manner.

\section{ETHYLENE INSERTION AND $\beta$ H ELIMINATION FOR PERMETHYLSCANDOCENE ALKYLS}

The rates of ethylene insertion into the $\mathrm{Sc}-\mathrm{C}$ bond for $\mathrm{Cp}{ }_{2} \mathrm{ScR}\left(\mathrm{R}=\mathrm{H}, \mathrm{CH}_{3}, \mathrm{CH}_{2} \mathrm{CH}_{3}, \mathrm{CH}_{2} \mathrm{CH}_{2} \mathrm{CH}_{3}\right)$ have been examined at $-80^{\circ} \mathrm{C}$ by ${ }^{13} \mathrm{C}$ NMR spectroscopy.

$$
\mathrm{Cp}^{*} \mathrm{Sc}-\mathrm{R}+\mathrm{CH}_{2}=\mathrm{CH}_{2} \stackrel{\mathrm{k}_{1}}{\longrightarrow} \mathrm{Cp}^{*}{ }_{2} \mathrm{ScCH}_{2} \mathrm{CH}_{2} \mathrm{R} \stackrel{\mathrm{CH}_{2}=\mathrm{CH}_{2}}{\longrightarrow} \text { etc. }
$$

The following second order rate constants $\left(\mathrm{k}_{1} ; \mathrm{M}^{-1} \cdot \mathrm{sec}^{-1},-80^{\circ} \mathrm{C}\right)$ have been measured: $\mathrm{R}=\mathrm{H}\left(>10^{-2}\right)$; $\mathrm{R}=\mathrm{CH}_{3}\left(8.1(2) \times 10^{-4}\right) ; \mathrm{R}=\mathrm{CH}_{2} \mathrm{CH}_{3}\left(4.4(2) \times 10^{-4}\right) ; \mathrm{R}=\mathrm{CH}_{2} \mathrm{CH}_{2} \mathrm{CH}_{3}\left(6.1(2) \times 10^{-3}\right)$. The fast rate for the hydride derivative is expected, and almost certainly is due to the greater overlap, hence better

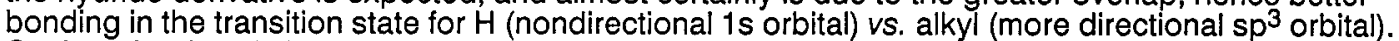
On the other hand, the greater insertion rate for the scandium propyl relative to the scandium methyl is likely due to ground state differences. Equilibrium measurements indicate that the relative ordering of $\mathrm{Sc}-\mathrm{R}$ bond dissociation energies (BDEs) mirrors that for the corresponding H-R BDEs (ref 3 ); hence, $\mathrm{BDE}\left(\mathrm{Sc}-\mathrm{CH}_{3}\right)-\mathrm{BDE}\left(\mathrm{Sc}-\mathrm{CH}_{2} \mathrm{CH}_{2} \mathrm{CH}_{3}\right) \geq \mathrm{ca}$. $6 \mathrm{kcal} \cdot \mathrm{mol}^{-1}$. The observation that the scandium ethyl complex is slowest to insert ethylene cannot be rationalized by these types of metal-carbon bond 
strength considerations or by transition state differences. Spectroscopic data and an X-ray diffraction study indicate a $\beta$ agostic interaction for the stable form of $\mathrm{Cp}^{*}{ }_{2} \mathrm{ScCH}_{2} \mathrm{CH}_{3}$. A similar $\beta$ agostic interaction is, of course, possible for $\mathrm{Cp}^{\star}{ }_{2} \mathrm{ScCH}_{2} \mathrm{CH}_{2} \mathrm{CH}_{3}$. Whereas such a structure (A) is electronically favored, it is sterically less favorable than the conventional structure (B), due to adverse interactions of the methyl group with a $\left(\eta^{5}-\mathrm{C}_{5} \mathrm{Me}_{5}\right)$ ligand.

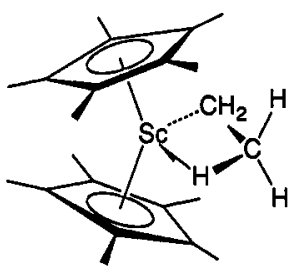

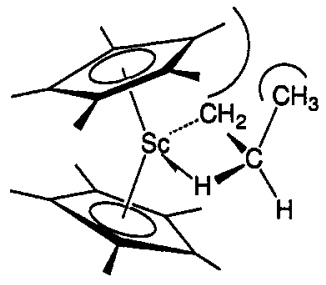

A

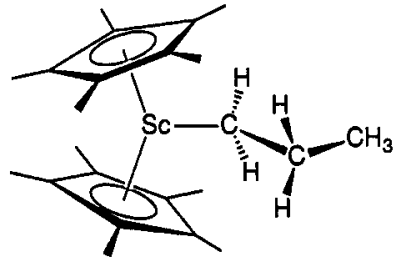

B

Presumably this $\beta$ agostic interaction for $\mathrm{Cp}^{*}{ }_{2} \mathrm{ScCH}_{2} \mathrm{CH}_{3}$ must be broken prior to ethylene insertion, thus increasing the barrier relative to the other alkyls. $\mathrm{Cp}^{\star}{ }_{2} \mathrm{ScCH}_{3}$ undergoes a single insertion with 2-butyne with a moderate enthalpy of activation $\left(\Delta \mathrm{H}^{\ddagger}=9.7(3) \mathrm{kcal} \cdot \mathrm{mol}^{-1}\right)$ and a large, negative entropy of activation ( $\Delta S^{\ddagger}=-36(20)$ eu), indicating highly ordered transition states for these insertion reactions.

The distributions of molecular weights for ethylene oligomers $\left(\mathrm{CH}_{3}\left(\mathrm{CH}_{2}\right)_{n} \mathrm{CH}_{3}, \mathrm{n}=11-47\right)$ produced from known amounts of ethylene and $\mathrm{Cp}^{*} \mathrm{ScCH}_{2} \mathrm{CH}_{2} \mathrm{CH}_{3}$ at $-78^{\circ} \mathrm{C}$ satisfactorily fit a Poisson distribution, indicative of a "living" Ziegler-Natta polymerization system. From the measured, slower initiation rates of insertion for $\mathrm{Cp}^{\star}{ }_{2} \mathrm{ScCH}_{3}$ and $\mathrm{Cp}^{*}{ }_{2} \mathrm{ScCH}_{2} \mathrm{CH}_{3}$ and propagation rates equal to that for $\mathrm{Cp}^{\star}{ }_{2} \mathrm{ScCH}_{2} \mathrm{CH}_{2} \mathrm{CH}_{3}$, the molecular weight distributions of ethylene oligomers are also predicted.

The rates for $\beta$ hydrogen elimination for members of the series of permethylscandocene alkyl complexes $\mathrm{Cp}_{2} \mathrm{ScCH}_{2} \mathrm{CH}_{2} \mathrm{R}\left(\mathrm{R}=\mathrm{H}, \mathrm{CH}_{3}, \mathrm{CH}_{2} \mathrm{CH}_{3}, \mathrm{C}_{6} \mathrm{H}_{5}, \mathrm{C}_{6} \mathrm{H}_{4}-p-\mathrm{CH}_{3}, \mathrm{C}_{6} \mathrm{H}_{4}-p-\mathrm{CF}_{3}, \mathrm{C}_{6} \mathrm{H}_{4}-\mathrm{p}-\mathrm{NMe}_{2}\right)$ have been obtained by rapidly trapping $\mathrm{Cp}^{\star}{ }_{2} \mathrm{Sc}-\mathrm{H}$ with 2 -butyne (eqs 4 and 5 ).

$$
\begin{aligned}
& \mathrm{Cp}^{*}{ }_{2} \mathrm{SC}-\mathrm{CH}_{2} \mathrm{CH}_{2} \mathrm{R} \stackrel{\mathrm{k}_{1}}{\longrightarrow} \mathrm{Cp}{ }_{2} \mathrm{SC}-\mathrm{H}+\mathrm{CH}_{2}=\mathrm{CHR} \\
& \mathrm{Cp}^{*}{ }_{2} \mathrm{SC}-\mathrm{H}+\mathrm{CH}_{3} \mathrm{C}-\mathrm{CCH}_{3} \longrightarrow \mathrm{E}-\mathrm{Cp}_{2}{ }_{2} \mathrm{SC}-\mathrm{C}\left(\mathrm{CH}_{3}\right)=\mathrm{CH}\left(\mathrm{CH}_{3}\right)
\end{aligned}
$$

For the phenylethyl series $k_{1}$ linearly correlates with $\sigma_{p}(R=0.9967)$ with a slope $(\rho)$ of $-1.87(11)$. A transition state for the $\beta$ hydrogen elimination is indicated with partial charge on the $\beta$ carbon. Hydrogen is thus transferred to the scandium center as hydride in the $\beta \mathrm{H}$ elimination process.

\section{OLEFIN DIMERIZATION, DIOLEFIN CYCLIZATION AND SKELETAL REARRANGEMENT WITH DIMETHYLSILYL-BRIDGED SCANDOCENE HYDRIDES}

Whereas $\mathrm{Cp}_{2}{ }_{2} \mathrm{ScH}$ ultimately generates (via $\sigma$ bond metathesis) permethylscandocene alkenyl complexes, $\mathrm{Cp}^{*} \mathrm{Sc}-\mathrm{CH}=\mathrm{CHR}$, with $\alpha$ olefins $\mathrm{CH}_{2}=\mathrm{CHR}$, less sterically encumbered scandocene hydrides $\left\{\left(\eta^{5}-\mathrm{C}_{5} \mathrm{Me}_{4}\right)_{2} \mathrm{SiMe}_{2}\right\} \mathrm{ScH}(\mathrm{OpScH})$ and $\left.\left[\left(\eta^{5}-\mathrm{C}_{5} \mathrm{H}_{3} \mathrm{CMe}_{3}\right)_{2} \mathrm{SiMe}_{2}\right\} \mathrm{ScH}\right]_{2}\left([\mathrm{DpScH}]_{2}\right)$ promote rapid, remarkably selective, head-to-tail dimerization of $\alpha$ olefins.

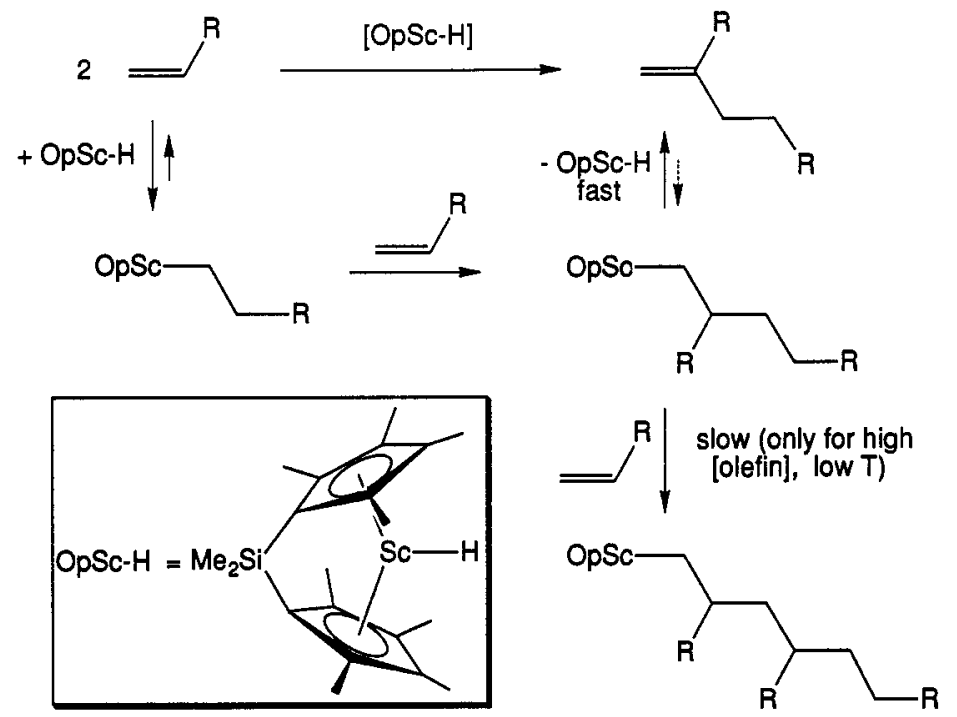


Moreover, $\alpha, \omega$ dienes are cleanly cyclized to the corresponding methylene cycloalkane. Cyclization of 1,4-pentadiene is endothermic; hence, catalytic opening of methylene cyclobutane to 1,4-pentadiene is observed. Unexpectedly, under more forcing conditions, 1,2-dimethylallyl scandocene is obtained. At $140^{\circ} \mathrm{C}$ catalytic conversion of 1,4-pentadienes to the corresponding isoprenes is observed, albeit with only a moderate number of turnovers (ref 4).
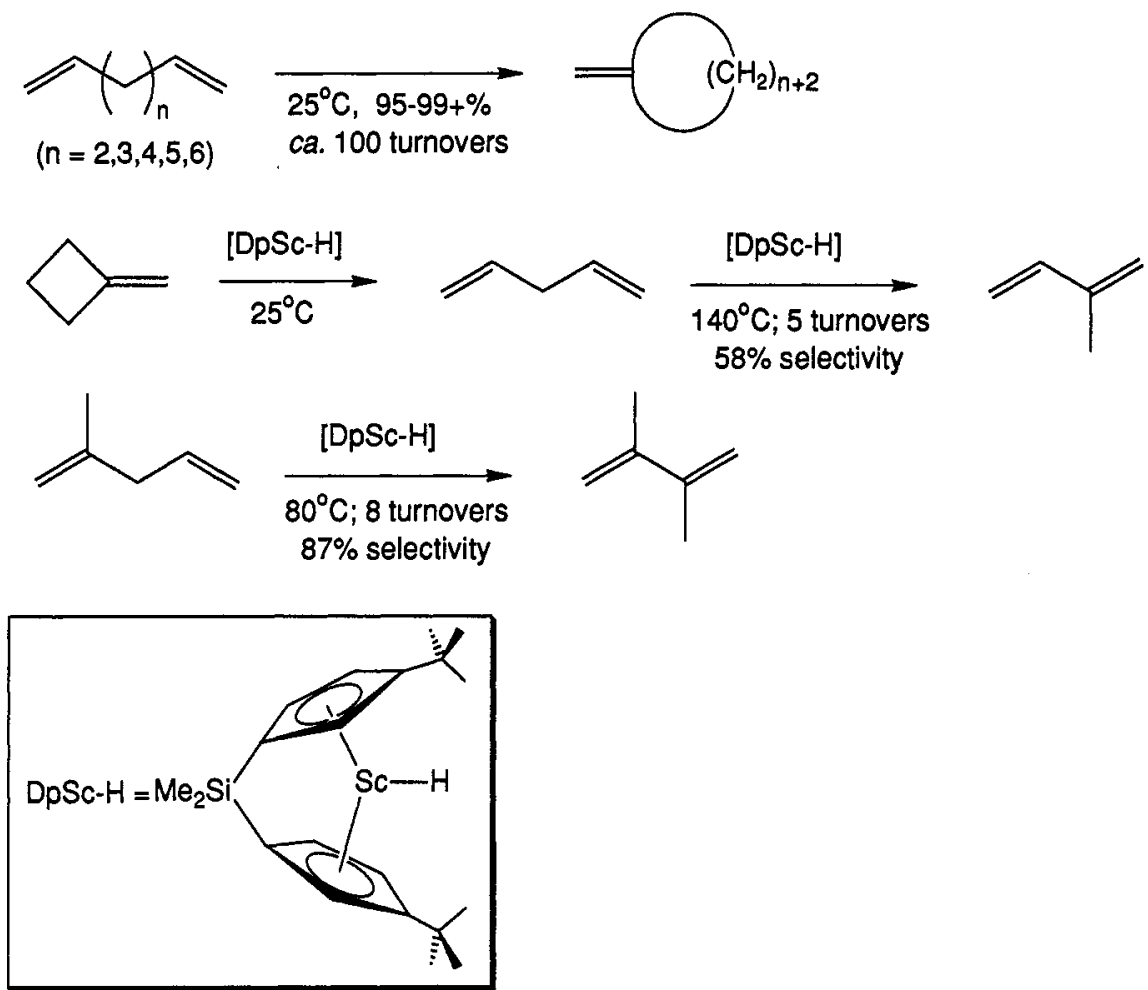

The (reversible) cyclization and branching of 1,4-dienes is proposed to occur via addition of $\mathrm{Sc}-\mathrm{H}$, followed by intramolecular olefin insertion to afford the (methylcyclopropylmethyl)scandium intermediate. The methyl branch is introduced by $\beta$ alkyl elimination in the alternate sense. $\beta \mathrm{H}$ elimination yields isoprene, which may readd to $\mathrm{DpScH}$ to yield the stable branched allyl derivative.
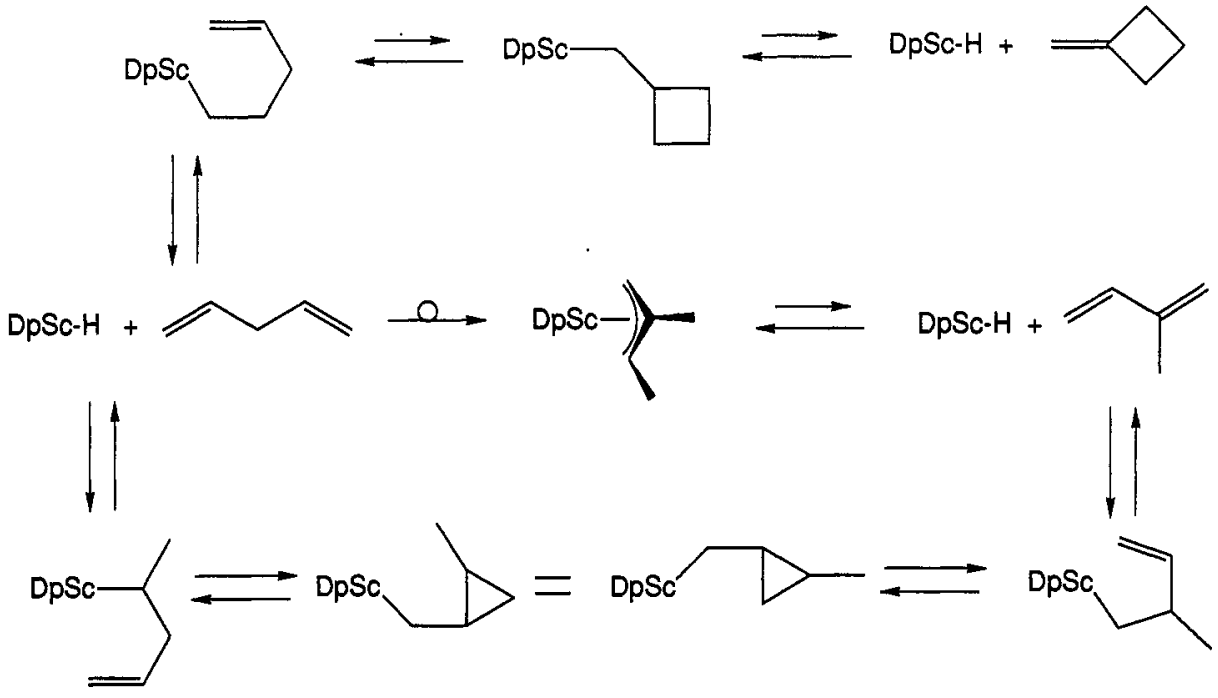

QUASI-LIVING $\alpha$ OLEFIN POLYMERIZATION WITH A DIMETHYLSILYLLINKED CYCLOPENTADIENYL-AMIDE LIGAND SYSTEM

Using the hydride derivative of scandium with the dimethylsilyl-linked cyclopentadienyl-amide ligand, $\left[\left\{\left(\eta^{5}-\mathrm{C}_{5} \mathrm{Me}_{4}\right) \mathrm{Me}_{2} \mathrm{Si}\left(\eta^{1}-\mathrm{NCMe}_{3}\right)\left(\mathrm{PMe}_{3}\right) \mathrm{Sc}(\mu-\mathrm{H})\right]_{2}\left(\left\{\left(\mathrm{Cp}^{\star} \mathrm{SiNR}\right)\left(\mathrm{PMe}_{3}\right) \mathrm{ScH}\right\}_{2}\right)\right.$, propene, 1-butene and 
1-pentene are cleanly, albeit slowly, polymerized with $>99 \%$ head-to-tail coupling to produce atactic polymers with $M_{n}=3,000-4,000$ and polydispersity indices of 1.7-2.1 (ref 5). Chain transfer is relatively slow. The molecular weight distributions for oligomers obtained at relatively low conversion of propene are adequately described by a Poisson function based on the amount of monomer consumed, assuming all scandium centers are participating, as a "living" system.

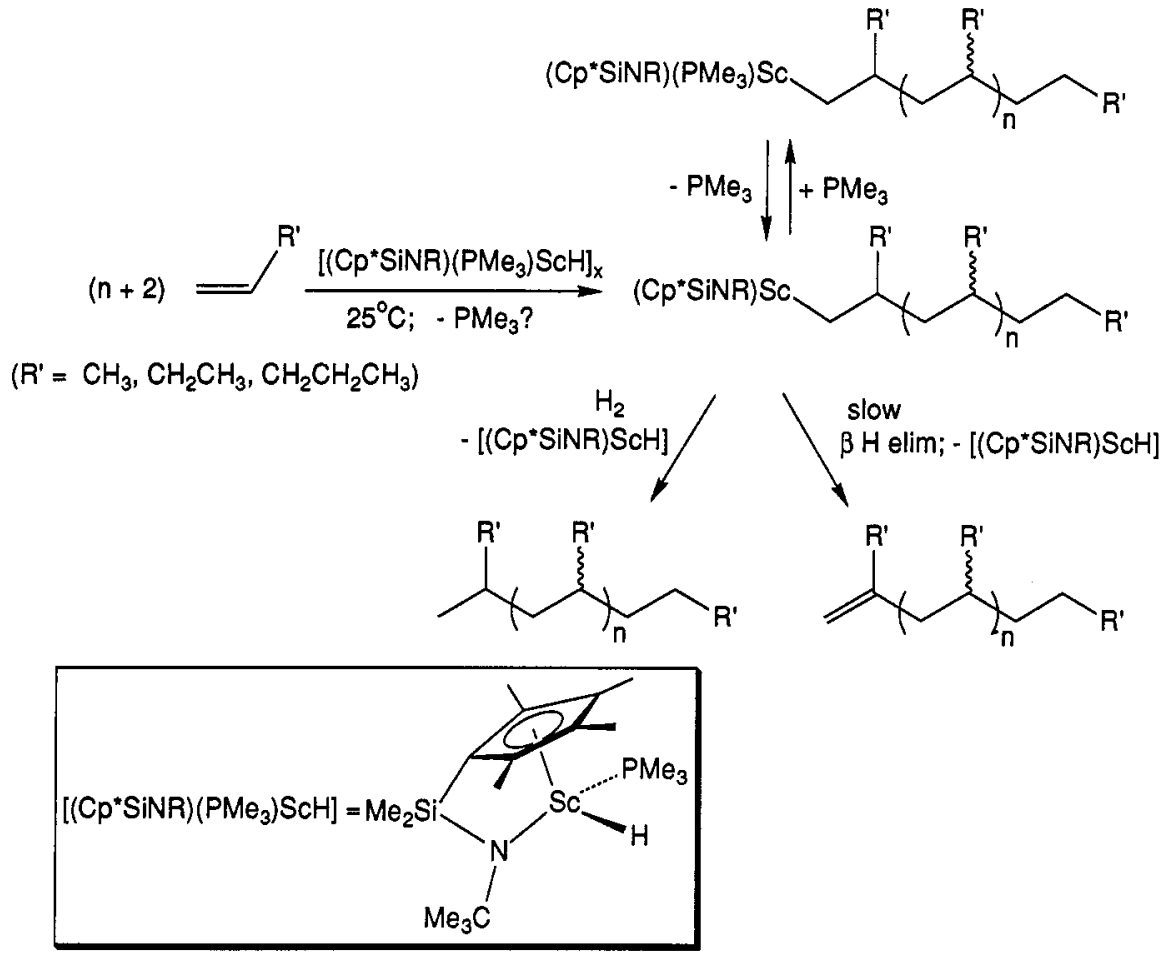

Acknowledgements The author wishes to thank those members of his research group, past and present, whose names are indicated in the references for their enthusiastic and insightful contributions to this work. Support from the USDOE Office of Basic Energy Sciences (Grant No. DE-FG03-85ER13431) and Shell Companies Foundation is gratefully acknowledged.

\section{REFERENCES}

1. (a) Thompson, M. E.; Bercaw, J. E. Pure and Appl. Chem. 56,1 (1984). (b) Parkin, G.; Bunel, E.; Burger, B. J.; Trimmer, M. S.; van Asselt, A.; Bercaw, J. E. J. Molecular. Catal. 41, 21 (1987). (c) Thompson, M. E.; Baxter, S. M.; Bulls, A. R.; Burger, B. J.; Nolan, M. C.; Santarsiero, B. D.; Schaefer, W. P.; Bercaw, J. E. J. Am. Chem. Soc. 109, 203 (1987).

2. Burger, B. J.; Thompson, M. E.; Cotter, W. D.; Bercaw, J. E. J. Am. Chem. Soc., submitted for publication.

3. Bulls, A. R.; Manriquez, J. M.; Thompson, M. E.; Bercaw, J. E. Polyhedron 7, 1409 (1988).

4. Bunel, E.; Burger, B. J.; Bercaw, J. E. J. Am. Chem. Soc. 110, 976 (1988).

5. Shapiro, P. J.; Bunel, E.; Schaefer, W. P.; Bercaw, J. E. J. Am. Chem. Soc., submitted for publication. 